\title{
PELATIHAN PENGGUNAAN MESIN PEMBUATAN PELLET PAKAN IKAN DALAM UPAYA PENINGKATAN PRODUKTIFITAS KELOMPOK PEMBUDIDAYAAN IKAN
}

\author{
Arif Setyo Nugroho ${ }^{1}$ \\ Sekolah Tinggi Teknologi Warga, Surakarta, Indonesia ${ }^{1}$ \\ Email: arifatw@gmail.com
}

\begin{abstract}
Abstrak
Penduduk kreatif Kelurahan Ngadirejo Kabupaten Sukoharjo melakukan budidaya dan pengembangan ikan lele, hasilnya sudah bisa dirasakan manfaatnya, tetapi mengalami kendala dalam pengembangan usaha pembudidayaan dan pengembangan ikan lele. Kendala atau permasalahn yang dihadapi adalah ketika harga pakan naik tetapi harga ikan hasil panen turun, sehingga FCR nya sangat kecil sehingga peternak rugi. Solusi yang ditawarkan sesuai hasil diskusi dengan PokDaKan adalah berusaha membuat pakan plus sehingga tidak tergantung dari pakan pabrik. Pakan lele berbentuk pelet dengan tambahan prebiotik untuk tambahan suplemen pakan lele dengan sentuhan teknologi dengan sistem mesin pengolah prebiotik sistem mix hot rotary dan mesin pembuat pellet apung. Teknologi tersebut sangat tepat untuk PokDaKan karena mampu menanggulangi permasalahan yang dihadapi. Mesin pellet bisa menghasilkan $80 \mathrm{~kg} /$ jam pelet. Dengan membuat sendiri pellet pakan ikan sesuai dengan yang dipraktekan, dengan modal uang Rp 500 ribu untuk belanja bahan pembuatan pellet bisa dibuat pelet kurang lebih $140 \mathrm{~kg}$ pellet. Lebih hemat dan pakan buatan sendiri lebih bergizi.
\end{abstract}

Kata Kunci: Pakan Lele, Prebiotik, Pellet, Bergizi, Ikan Lele.

\section{Abstract}

The creative inhabitants of Ngadirejo Sub-district, Sukoharjo Regency, cultivate and develop catfish, the results can be felt the benefits, but have experienced obstacles in developing catfish cultivation and development businesses. The constraints or problems faced are when the price of feed rises but the price of the harvested fish goes down, so the FCR is very small so that the farmer loses. The solution offered in accordance with the results of discussions with PokDaKan is to try to make plus feed so that it does not depend on factory feed. Catfish feed is in the form of pellets with the addition of prebiotics for additional catfish feed supplements with a touch of technology with a prebiotic processing machine system, a hot rotary mix system and a floating pellet making machine. This technology is very appropriate for PokDaKan because it can overcome the problems it faces. The pellet machine can produce $8 \mathrm{o} \mathrm{kg} /$ hour of pellets. By making your own fish feed pellets in accordance with what is practiced, with a capital of IDR 500 thousand to spend on materials for making pellets, you can make pellets of approximately $140 \mathrm{~kg}$ of pellets. It is more economical and homemade feed is more nutritious.

Keywords: Feed Catfish, Prebiotics, Pellets, Nutritious, Catfish.

\section{PENDAHULUAN}

\section{Analisis Situasi}

Sebagai usaha kreatif yang dilakukan oleh Sebagian masyarakat di Kelurahan Ngadirejo kabupaten Sukoharjo yaitu pengembanan budidaya ikan lele, ternyata dari usha kreatif yang menjadi usaha sambilan membawa keuntungan sebagai nilai tambah 
$\overline{\text { keluarga. Memanfaatkan lahan di sekitar rumah dengan membuat kolam permanen }}$ maupun tidak permanen. Kelompok budidaya dan pengembangan ikan jenis lele di Kelurahan Ngadirejo Kabupaten Sukoharjo disingkat PokDaKan. Dalam kelompok tersebut berkonsentrasi dalam pembibitan, pembesaran dan pakan ikan lele.

Karena mereka tinggal dalam wilayah yang sama yaitu satu Kelurahan, memungkinkan usaha mereka cepat maju dan komunikasi antar anggota PokDaKan tidak terganggu, bila ada permasalahan. Sesuai dengan cita-cita anggota ketika sepakat membentuk PokDaKan yaitu ingin maju dan berkembang, dari anggota untuk kesejahteraan anggota dengan peningkatan hasil dari usaha sampingan yaitu budidaya dan pembesaran ikan lele. Salah satu cara memanfaatkan lahan kosong di sekitar rumah adalah dengan cara beternak ikan. Keinginan untuk lebih maju ingin berkembang dan ingin menjadi salah satu kelompok yang ingin mewujudkan Kelurahan Ngadirejo menjadi sentra olahan ikan lele dan industri lele. Cita-cita tersebut mempunyai dasar yang kuat, mengingat kebutuhan ikan lele siap dikomsumsi setiap tahun meningkat terutama ketika mendekati hari raya. Kebutuhan akan ikan lele luar biasa tinggi, jumlah kebutuhan ikan lele di Surakarta dan sekitarnya sebanyak 12 ton perbulan rata rata pertahun. Bisnis Indonesia 29 Januari 2018 menjelaskan target 2018 produksi lele ditingkatkan menjadi 24,1 juta ton. Tantangan pemenuhan kebutuhan tersebut menjadi inspirasi dan motivasi anggota PokDaKan. Tantangan tersebut adalah pemenuhan kebutuhan ikan lele untuk mensuplai pasar di sekitar Surakarta, Sukoharjo dan Klaten sebanyak 1 ton per bulan, dan baru bisa memenuhi hampir $60 \%$.

Kualitas dan sirkulasi air harus diperhatikan dalam budidaya ikan lele, kualitas air yang dimaksud adalah suhu air dan kadar oksigen dalam air. Selain air yang harus di perhatikan juga masalah pakan. Pakan adalah salah satu komponen utama dalam budidaya ikan lele, pakan yang berkualitas dapat menambah berat ikan lele. Dalam perkembangannya, budidaya ikan lele di Kelurahan Ngadirejo yang tergabung dalam kelompok usaha PokDaKan mengalami permasalahan mengenai pakan sehingga kegiatan PokDaKan menjadi tidak bisa berkembang. Permasalahan timbul karena harga pakan pabrikan melambung tinggi sementara harga jual lele tidak naik dan cenderung turun ketika panen lele. Solusi yang dibuat adalah dengan cara membuat pakan sendiri dengan ditambah kan prebiotik sebagai tambahan nutrisi. Diharapkan dengan membuat pakan plus prebiotik permasalahan mengenai pakan bisa teratasi tidak tergantung dengan pakan pabrikan. Pemberian pakan yang mengandung nutrisi sesuai kebutuhan ikan lele sangatlah penting karena pakan diperlukan untuk pemeliharaan, pertumbuhan dan reproduksi. Manajemen pakan yang baik dengan menambahkan probiotik bakteri pada pakan. Semakin banyak bakteri pada pakan akan dapat menghasilkan energi yang sangat dibutuhkan ikan lele dalam tumbuh berkembang.

Penambahan prebiotik dalam pakan dapat menanggulangi beberapa penyakit,karena prebiotik adalah mikroba hidup yang dapat memberikan keuntungan 
bagi inang dengan mengatur keseimbangan mikroba dalam saluran pencernaan ikan lele. Agar bisa berkemang maka dilakukan beberapa Langkah terobosan, antara lain pembuatan pakan dengan tambahan prebiotik hasil ramuan dari anggota kelompok dan melakukan pembibitan ikan lele dengan mengambil indukan yang terbaik. Tentunya benih ikan lele hanya untuk kebutuhan kelompok budidaya ikan di Kelurahan Ngadirejo Sukoharjo. Pembuatan pakan berbentuk pellet, untuk produksi secara maksimal untuk kebutuhan anggota diperlukan mesin pembuat pellet, guna membuat ramuan prebiotik diperlukan mesin pengaduk dengan RPM rendah dan dipanasi dengan temperature antara $40^{\circ} \mathrm{C}-60^{\circ} \mathrm{C}$.

\section{Solusi dan Target}

Solusi yang ditawarkan dalam Program Kemitraan Masyarakat adalah dengan pendekatan yang dilakukan bersifat “bottom up", dimana perencanaan tindakan diupayakan menjawab permasalahan dan kebutuhan UKM mitra (PokDaKan) dilakukan secara partisipatif.

a. Solusi Pertama : Pengadukan bahan baku pembuatan prebiotik dan dengan pengaturan temperatur. Pembuatan pellet dengan mesin vertikal penggerak motor bakar diharapkan mampu menghasilkan pelet 85 kg/jam. Hasil Diskusi Tim Program Kemitraan Masyarakat dan PokDaKan menghasilkan pemikiran sebuah mesin yang berbentuk tabung tertutup dilengkapi dengan pengaduk otomatis dengan RPM rendah dilengkapi pemanas yang diatur panasnya. Temperatur panas dari kompor LPG yang dilengkapi dengan nozel dan thermoreader.

b. Solusi Kedua : penambahan bahan untuk pembuatan pelet apung.

Dari permasalahan yang dihadapi PokDaKan, dan hasil diskusi dengan mitra sepakat untuk solusinya sebagai berikut :

a. Membuat mesin pengolah prebiotik dengan sistem mix hot rotary. Temperatur $40^{\mathrm{O}}$ C-6o ${ }^{\mathrm{O}} \mathrm{c}$ konstan, tekanan $1 \mathrm{~atm}$.

b. Membuat mesin pembuat granule kontinyu dengan kapasitas $85 \mathrm{~kg} / \mathrm{jam}$.

c. Pembuatan alur pengerjaan dan distribusi ke anggota kelompok.

d. Diadakan pelatihan penggunaan mesin bagi anggota kelompok yang ditugasi.

e. Untuk mengetahui hasil kerja maka dilakukan pelatihan pembuatan manajemen keuangan yang baik.

\section{METODE}

Masukan dari PokDaKan mengenai permasalahan yang dihadapi merupakan masukan yang penting untuk segera ditangani, penangannya harus sistimatis, terarah dan efisien. Komunikasi dengan PokDaKan merupakan hal yang utama, karena PokDaKan adalah merupakan pengguna. Tim Program Kemitraan Masyarakat memberikan beberapa gambaran penggunaan teknologi, masukan dari UKM mengenai teknologi tersebut sangat berarti. Sinergi keilmuan, pengalaman lapangan yang dimiliki tim Program Kemitraan Masyarakat dan pengalaman dari PokDaKan merupakan modal awal untuk menyelesaikan masalah yang dihadapi. 
Adapun dalam hal ini UKM mempunyai fungsi yang penting terutama dalam mendukung pelaksanaan program ini :

1. Memberikan data yang solid dalam menunjang proses pembuatan mesin yang direncanakan.

2. Aktif memberi masukan dalam perencaanan dan desain alat.

3. Melakukan uji coba mesin sampai mengetahui hasil yang diharapkan.

4. Pemeliharaan alat yang telah dibuat dan sebagai solusi permasalahan ,memanfaatkan mesin atau alat tersebut secara kebersamaan.

Hasil diskusi tersebut mengerucut pada :

1. Dibutuhkan mesin pengolah prebiotik dengan sistem mix hot rotary.

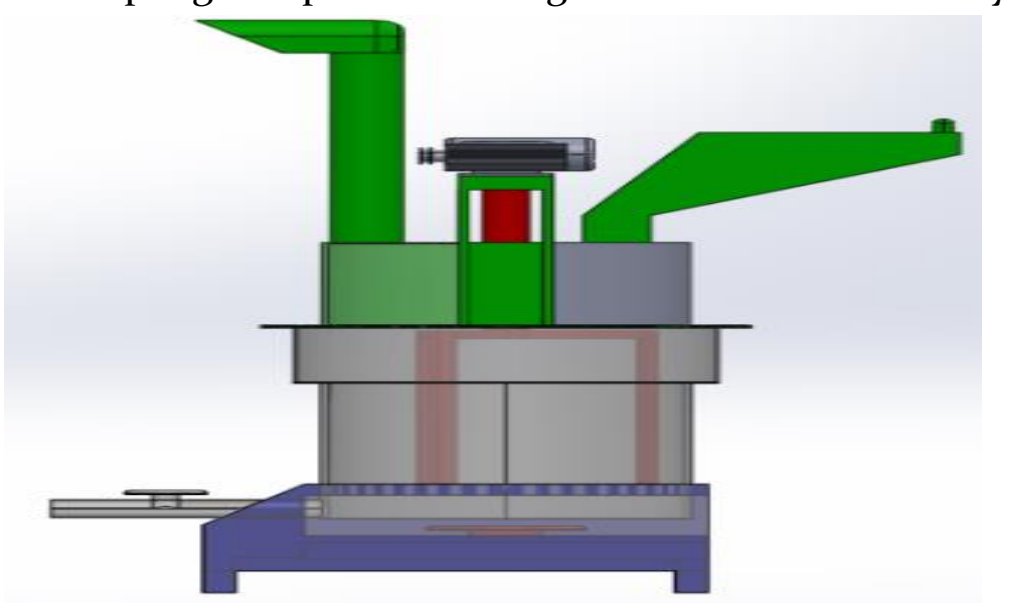

Gambar 1. Mesin Pengolah Prebiotik Dengan Sistem Mix Hot Rotary

Mesin tersebut digunakan untuk mengaduk, mencampur bahan baku nutrisi tambahan prebiotik dan bahan utama granul pellet. Dibutuhkan panas yang cukup antara $45^{\mathrm{O}} \mathrm{C}-65^{\mathrm{O}} \mathrm{c}$ secara kostan. Pemanasan dan juga pengadukan dengan rpm rendah kurang lebih $60 \mathrm{rpm}$. Penggerak menggunakan motor listrik 0.5 PK, dilengkapi dengan reduser. Reduser terhubung dengan poros. Poros berfungsi untuk mengaduk adonan prebiotik, dengan putaran 6o putaran perdetik. Kapasitas produksi 25 liter.

2. Dibutuhkan mesin pembuat granulle pellet

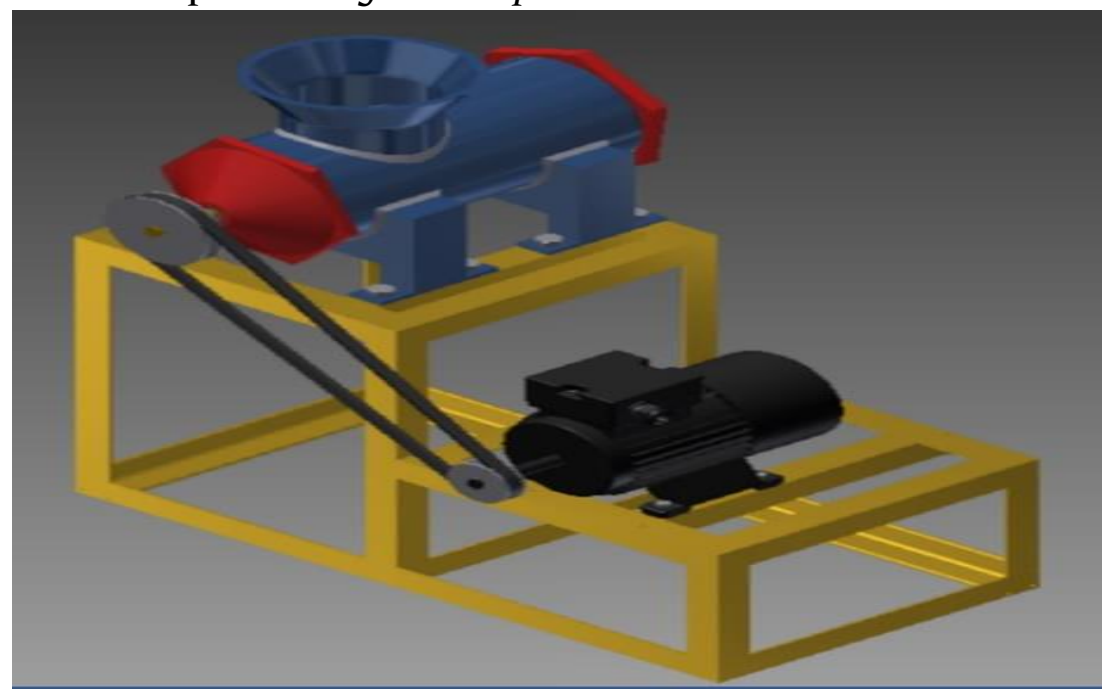

Gambar 2. Mesin Granul Pellet Pakan Ikan 
Gambar 2 adalah mesin pembuat granule pellet ikan, dengan penggerak motor bakar 5 PK. Mudah dan aman dalam pengoperasiannya. Mesin granule tersebut direncanakan mampu memproduksi pellet kurang lebih $85 \mathrm{~kg} / \mathrm{jam}$. Granule dengan bahan baku dari penelitian otodidak dari peternak kemudian diaplikasikan dengan menggunakan mesin.

Diameter pellet $3 \mathrm{~mm}$. Pellet yang dihasilkan bisa pellet tenggelam maupun pellet apung dengan menambah beberapa campuran bahan pakan, sehina berat dari pellet berkurang tetapi nutrisinya lebih baik.

Diharapkan dengan peralatan tersebut di atas kemampuan berkembang PokDaKan lebih cepat, tidak tergantung lagi dengan pakan pabrikan. Sehingga diharapkan ternak lele khususnya pembesaran ikan lele tidak terganggu dengan naik turunya harga pakan ikan lele, karena bisa mencukupi kebutuhan anggota PokDaKan.

Mesin digerakan dengan motor bakar, mesin granul pellet terdiri dari hoper (tempat adonan pellet, lempeng berlubang dari besi ST 45 dan screw penekan, mesin ini bergerak secara rotary continyu.

\section{HASIL DAN PEMBAHASAN}

Hasil diskusi yang baik antara UKM PokDaKan Ulam Lumintu dengan Tim Pengabdian menghasilkan produk yang baik, produk yang bisa digunakan dan dapat membantu peternak ikan lele dan pembesaran ikan lele yang tergabung dalam PokDaKan. Tahapan demi tahapan dilaksanakan sesuai dengan perencanaan. Peran serta PokDaKan sangat berarti, masukan dalam perencanaan merupakan hal yang sangat berarti untuk menghindari permasalahan yang substansial.

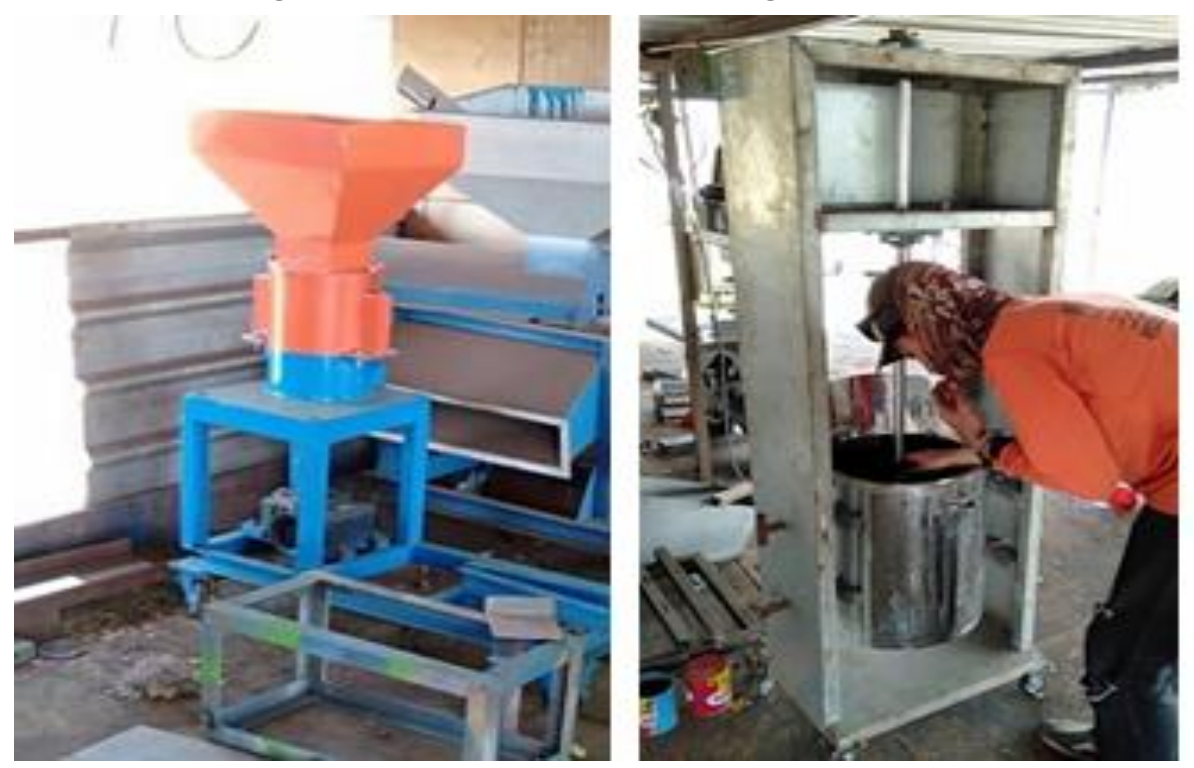

Gambar 3. Fabrikasi Mesin Pellet dan Pembuatan Pebriotik

Mesin pembuat prebiotik berbahan baku plat stenlis dan kerangka terbuat dari besi kanal C. Kapasitas 25 liter, penggerak menggunakan motor listrik 0.5 PK dan reducer untuk memperlambat putaran. Putaran poros 70 putaran per menit, poros 
terbuat besi pejal stenlis. Pemanas menggunakan LPG, Ketinggian konstruksi $190 \mathrm{~cm}$, lebar $50 \mathrm{~cm}$, panjang $75 \mathrm{~cm}$. Bak pembuat dibuat berlapis deantara lapisan diberi minyak atau air sehingga panasnya menjadi rata. Mesin pellet yang dibuat menggunakan penggerak motor bakar $5 \mathrm{PK}$, mesin pellet vertikal dengan poros dilengkapi gerigi pendesak, lempengan dilubangi $4 \mathrm{~mm}$ dengan ketebalan lempengan $15 \mathrm{~mm}$ dilengkapi pengatur panjang pendek pellet. Mesin pellet bisa menghasilkan 8o $\mathrm{kg} /$ jam baik pellet apung maupun tenggelam.

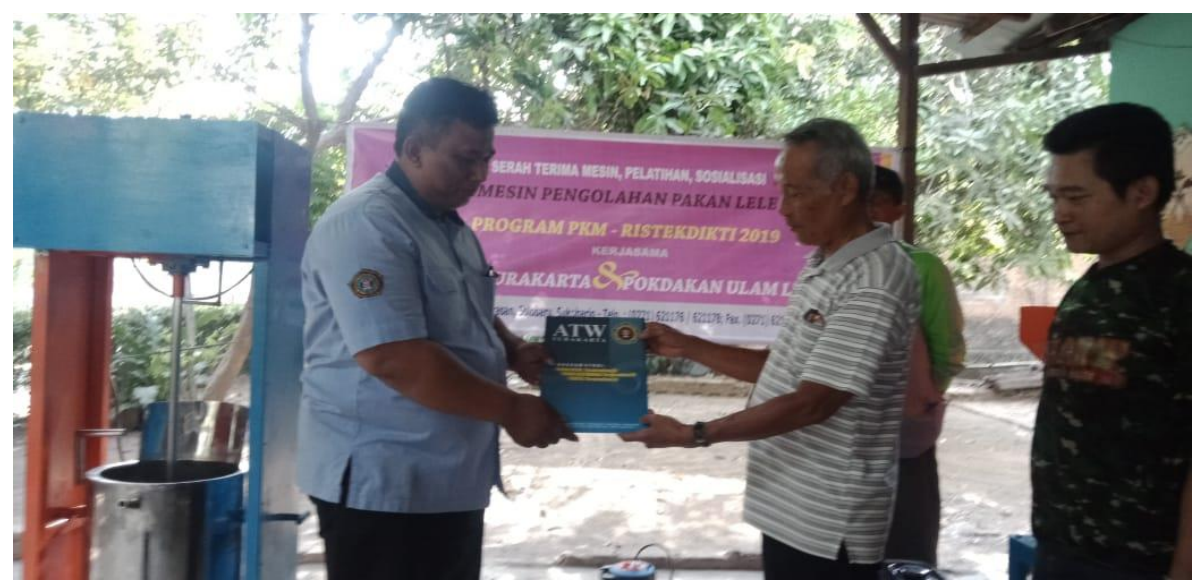

Gambar 4. Penyerahan Mesin
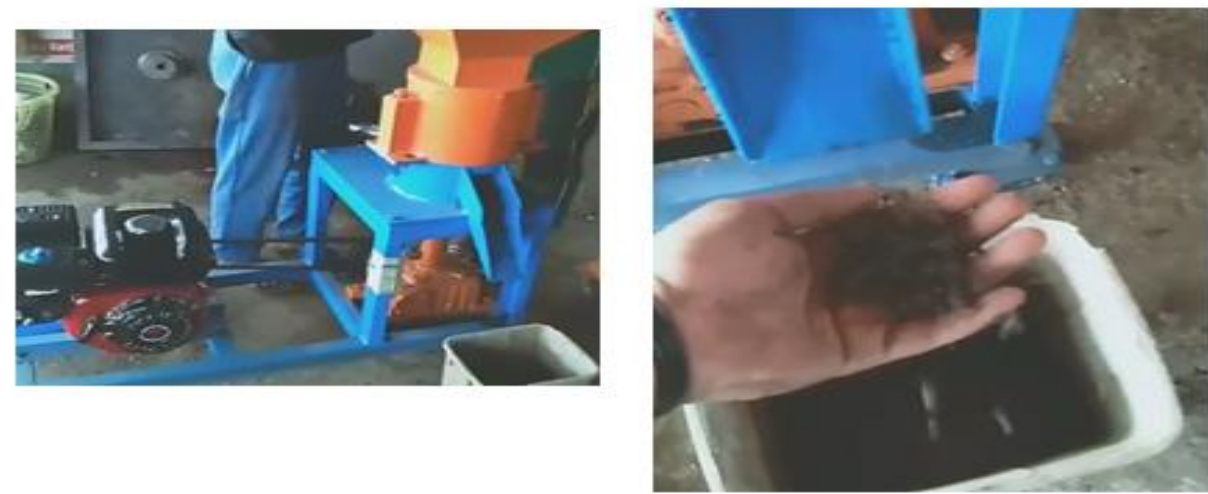

Gambar 5. Pengujian Mesin Pellet

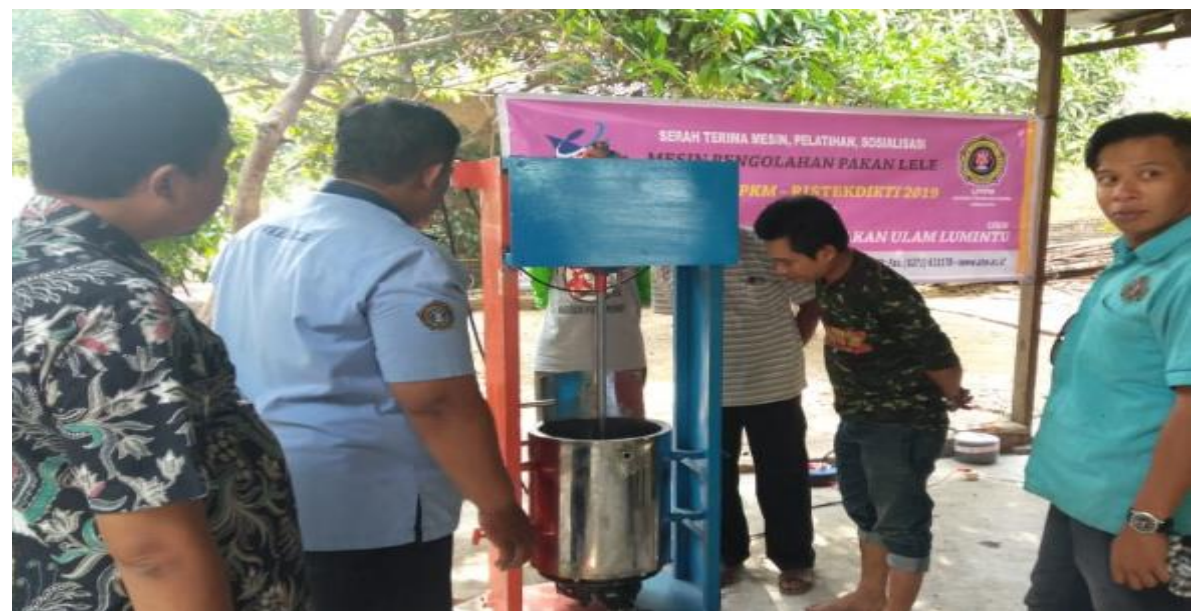

Gambar 6. Pelatihan pada UKM Pok Da Kan 
Setelah mesin jadi maka dilakukan penyerahan mesin dan pelatihan penggunaan oleh UKM mitra yaitu PokDaKan seperti terlihat di gambar 4, 5, dan 6. Tetap dilakukan pendampingan oleh tim PKM, sehingga mesin tersebut memang bisa digunakan dan bermanfaat. Teknologi tersebut sangat tepat untuk PokDaKan karena mampu menanggulangi permasalahan yang dihadapi. Mesin pellet bisa menghasilkan 8o $\mathrm{kg} /$ jam pelet. Dengan membuat sendiri pellet pakan ikan sesuai dengan yang dipraktekan, dengan modal uang Rp 500 ribu untuk belanja bahan bahan pembuatan pellet bisa dibuat pelet kurang lebih $140 \mathrm{~kg}$ pellet. Lebih hemat dan pakan buatan sendiri lebih bergizi.

\section{KESIMPULAN}

Pelaksanaan kegiatan yang telah dilakukan dalam program kemitraan masyarakat dengan UKM PokDaKan didapatkan beberapa kesimpulan diantaranya yaitu keberhasilan tim pelaksana melakukan rekayasa mesin pembuat prebiotik campuran pakan lele dan pakan lele berbentuk pellet plus dapat diterapkan mitra pengguna dan sekaligus mengatasi permasalahan mitra kegiatan. Mesin pellet bisa menghasilkan 8o $\mathrm{kg} / \mathrm{jam}$ baik pellet apung maupun tenggelam. Mesin pellet bisa menghasilkan 8o $\mathrm{kg} /$ jam pelet. Dengan membuat sendiri pellet pakan ikan sesuai dengan yang dipraktekan, dengan modal uang Rp 500 ribu untuk belanja bahan bahan pembuatan pellet bisa dibuat pelet kurang lebih $140 \mathrm{~kg}$ pellet. Lebih hemat dan pakan buatan sendiri lebih bergizi.

\section{REFERENSI}

Aisin Umasugi, E. L. G., Tumbol, Reiny A., Kreckhoff, Reni L., Manoppo, Henky., Pangemanan, Novie Novie P.L. (2018). Penggunaan Bakteri Probiotik Untuk Pencegahan Infeksi Bakteri Streptococcus Agalactiae Pada Ikan Nila. Oreochromis Niloticus," Budidaya Perairan, 6(2), 39-44.

Fauziyah, Nur., Nirmala, Kukuh., Supriyono, Edy., Hadiroseyani, Yani. (2019). Evaluasi Sistem Budidaya Lele: Aspek Produksi Dan Strategi Pengembangannya. Jurnal Kebijakan Sosial Ekonomi Kelautan dan Perikanan, 9(2), 129-142.

Nugroho, Arif Setyo., Rahayu, Aris Teguh., Kristiawan, Y Yulianto. (2019). Peningkatan Hasil Ternak Lele dengan Pengolahan Pakan Plus Secara Mandiri. Suluah Bendang: Jurnal Ilmiah Pengabdian Masyarakat, 19(3), 135-143.

Putri, Dwi Utami., Aliyas. (2019). Pengaruh Pemberian Pakan dengan Dosis Berbeda Terhadap Pertumbuhan dan Kelangsungan Hidup Benih Ikan Lele (Clarias SP) Dalam Media Bioflok. TOLIS Ilmiah: Jurnal Penelitian, 1(2), 92-100.

Wardika, Aziz Sinung. (2017). Efektivitas Penambahan Bakteri Probiotik dengan Dosis Berbeda dalam pakan terhadap Efisiensi Pemanfaatan Pakan, Pertumbuhan dan Kelulushidupan Ikan Lele Dumbo (Clarias gariepinus). Jurnal Sains Teknologi Akuakultur, 1(1), 21-30.

Widagdo, Barru Anggoro., Elfitasari, Tita., Basuki, Fajar. (2006). "Strategi 
E-ISSN: 2776-3331

Vol. 1, No. 1, pp.48-55

Mei 2021

Pengembangan Budidaya Pembesaran Ikan Lele (Clarias Sp) Di Kecamatan Gunung Pati Kota. Prosiding Seminar Nasional Tahun ke V, Hasil-hasil Penelitian Perikanan dan Kelautan.

Yuriana, lely., Santoso, Handoko., Sutanto., Agus. (2017). Pengaruh Probiotik Strain Lactobacillus Terhadap Laju Pertumbuhan Dan Efisiensi Pakan Lele Masamo ( Clarias sp ) Tahap Pendederan I Dengan Sistem Bioflog. Jurnal Lentera Pendidikan Pusat Penelitian LPM Um Metro, 2(1), 13-23. 